\title{
Baicalein, Ethyl Acetate, and Chloroform Extracts of Scutellaria baicalensis Inhibit the Neuraminidase Activity of Pandemic 2009 H1N1 and Seasonal Influenza A Viruses
}

\author{
Mann-Jen Hour, ${ }^{1}$ Su-Hua Huang, ${ }^{2}$ Ching-Yao Chang, ${ }^{2}$ Yen-Kuan Lin, ${ }^{2,3}$ \\ Ching-Ying Wang, ${ }^{3,4}$ Yuan-Shiun Chang, ${ }^{4}$ and Cheng-Wen Lin ${ }^{2,3}$ \\ ${ }^{1}$ School of Pharmacy, China Medical University, No. 91 Hsueh-Shih Road, Taichung 40402, Taiwan \\ ${ }^{2}$ Department of Biotechnology, Asia University, No. 500 Lioufeng Road, Wufeng, Taichung 41354, Taiwan \\ ${ }^{3}$ Department of Medical Laboratory Science and Biotechnology, China Medical University, No. 91 Hsueh-Shih Road, \\ Taichung 40402, Taiwan \\ ${ }^{4}$ School of Chinese Pharmaceutical Sciences and Chinese Medicine Resources, China Medical University, No. 91 Hsueh-Shih Road, \\ Taichung 40402, Taiwan
}

Correspondence should be addressed to Cheng-Wen Lin; cwlin@mail.cmu.edu.tw

Received 16 April 2013; Accepted 26 May 2013

Academic Editor: Il-Moo Chang

Copyright (C) 2013 Mann-Jen Hour et al. This is an open access article distributed under the Creative Commons Attribution License, which permits unrestricted use, distribution, and reproduction in any medium, provided the original work is properly cited.

\begin{abstract}
This study rated antiviral activity of Scutellaria baicalensis Georgi (S. baicalensis) extracts against influenza A virus subtypes, for example, pandemic 2009 H1N1, seasonal H1N1 and H3N2. Ethyl acetate (EtOAc) and chloroform extracts inhibited in vitro neuraminidase (NA) enzymatic activity and viral replication more than methanol $(\mathrm{MeOH})$ extract. EtOAc extract demonstrated NA inhibition $\mathrm{IC}_{50}$ values ranging from 73.16 to $487.40 \mu \mathrm{g} / \mathrm{mL}$ and plaque reduction $\mathrm{IC}_{50}$ values ranging from 23.7 to $27.4 \mu \mathrm{g} / \mathrm{mL}$. Chloroform extract showed antiviral activities with plaque reduction $\mathrm{IC}_{50}$ values ranging from 14.16 to $41.49 \mu \mathrm{g} / \mathrm{mL}$ Time-ofaddition assay indicated that EtOAc and chloroform extracts also significantly inhibited virus yields after infection. HPLC analysis demonstrated that baicalin was dominant in the $\mathrm{MeOH}$ extract; baicalein and chrysin were rich in the EtOAc and chloroform extracts. Molecular simulation revealed baicalein hydrogen bonding with Glu277 as well as hydrophobic and Van der Waals interactions with Ile222, Arg224, Ser246, and Tyr347 in NA1 active sites of NA1. Baicalein inhibited in vitro replication of influenza A viruses pandemic $2009 \mathrm{H} 1 \mathrm{~N} 1\left(\mathrm{IC}_{50}=0.018 \mu \mathrm{M}\right)$ and seasonal $2007 \mathrm{H} 1 \mathrm{~N} 1 \mathrm{using}$ plaque reduction assays. A combination of lowdose baicalein with other anti-influenza agents could be applicable for development of alternative remedies treating influenza A virus infection.
\end{abstract}

\section{Introduction}

Influenza A virus, a member of the Orthomyxoviridae family, is an enveloped virus containing eight segmented, negativesense, single-stranded RNAs [1,2]. The viral genome encodes 10 proteins, for example, hemagglutinin (HA), neuraminidase (NA), M1, M2, nonstructural protein 1 (NS1), NP, and RNP. $\mathrm{HA}, \mathrm{NA}$, and M2 locate on the outer side of a viral envelope and $\mathrm{M} 1$ on the inner side. Of these envelope proteins, HA contains the receptor-binding site, being responsible for virus fusion and infectivity [3]. NA digests sialic acid on the cell surface, resulting in release of virus particles and spread of the virus. M2 ion channel modulates the acidic $\mathrm{pH}$ of the endosome, allowing the acidification of the internal virion core as well as causing release of vRNP into cell cytoplasm. Envelope proteins (HA, NA, and M2) play key roles in viral infectivity, making them prime targets for prophylaxis and therapeutic anti-influenza A virus drugs. Still, oseltamivirresistant and amantadine-resistant variants emerge and are identified in several countries [4-9], creating a need to develop new anti-influenza compounds.

Influenza A virus consists of $17 \mathrm{HA}$ and $10 \mathrm{NA}$ subtypes [10]. Human influenza A viruses H1N1 and H3N2 subtypes commonly cause acute respiratory disease. Avian influenza 
viruses $\mathrm{H} 5 \mathrm{~N} 1, \mathrm{H} 7 \mathrm{~N} 3, \mathrm{H} 7 \mathrm{~N} 7$, and H9N2 subtypes occasionally infect humans [11]. A 2009 reassortment (pandemic 2009 H1N1) of avian, swine, and human influenza A viruses caused global outbreak, first human pandemic of its kind in the 21st century [12, 13]. Pandemic 2009 H1N1 rapidly spread worldwide, infecting 1 to 3 billion people from April 2009 to August 2010. Its virus replicates in mucosal epithelial cells of upper and lower airways, lung pneumocytes, alveolar macrophages, mucous glands, and lymph nodes, causing pathology similar to $1918 \mathrm{H} 1 \mathrm{~N} 1$ and $\mathrm{H} 5 \mathrm{~N} 1$ viruses $[14,15]$. Oseltamivir-resistant pandemic $2009 \mathrm{H} 1 \mathrm{~N} 1$ isolates with $\mathrm{H} 275 \mathrm{Y}$ mutation in NA were identified in 2010 [16]; drug-resistant pandemic 2009 H1N1 variants increased worldwide [17]. Importantly, a novel avian-origin influenza A (H7N9) virus causes an outbreak with severe and fatal respiratory diseases in China in 2013 [18], becoming global public health concerns, such that new therapies and vaccines against influenza infection become urgent.

Scutellaria baicalensis Georgi ("Huang-Qin" in Chinese) is a traditional Chinese medicinal herb exhibiting many biological activities, for example, antipyretic, antibacterial, antiviral, and/or anti-inflammatory properties [19]. Extracts of $S$. baicalensis inhibit growth of urothelial carcinoma cells [20], inducing apoptosis of human monocytic leukemia and osteogenic sarcoma cells [21]. S. baicalensis extracts modulate production of cytokines, linking with the antiviral activity [22]. Baicalin, baicalein, wogonin, wogonin 7-Oglucuronide, oroxylin A, oroxylin A 7-O-glucuronide, apigenin, and chrysin are major and bioactive components of S. baicalensis [23]. Baicalin and baicalein inhibit viral replication of parainfluenza [24], influenza A [25], hepatitis B [26], HIV-1 [27], and SARS coronavirus [28]. Wogonin inhibits hepatitis $B$ surface antigen secretion while reducing HBV-DNA level in vitro, as confirmed by the animal model infected with duck hepatitis B virus [29]. Apigenin also inhibits in vitro replication of influenza and adenoviruses [30]. In our laboratory, S. baicalensis water extract shows inhibitory effects on in vitro enzymatic activity of influenza A virus NA. This study further probes antiviral activity of ethyl acetate (EtOAc), methanol $(\mathrm{MeOH})$, and chloroform extracts against influenza A virus subtypes like pandemic 2009 H1N1 and seasonal influenza A viruses H1N1 and H3N2. In addition, molecular simulation and in vitro assays indicated flavonoids of S. baicalensis, such as baicalein and baicalin, as potentials of NA inhibitory agents.

\section{Materials and Methods}

2.1. Viruses and Cells. Pandemic influenza A/Taiwan/ CMUH/2009 (H1N1) (pandemic 2009 H1N1 virus), seasonal influenza A/Taiwan//CMUH/2007 (H1N1), 2009 (H1N1), and 2009 (H3N2) (seasonal $2007 \mathrm{H} 1 \mathrm{~N} 1,2009 \mathrm{H} 1 \mathrm{~N} 1$, and 2009 H3N2 influenza A viruses) were isolated in the clinical virology laboratory of China Medical University Hospital, Taiwan. Influenza A/Puerto Rico/8/34 (H1N1) (PR8 H1N1 virus) was kindly provided by Dr. Wei-Li Hsu (Institute of Microbiology and Public Health, National Chung-Hsing University). HA subtype of all influenza
A viruses used was confirmed by RT-PCR or real-time RT-PCR with specific primers (see Supplementary Table 1 in the Supplementary Material available online at http://dx .doi.org/10.1155/2013/750803).

Madin-Darby canine kidney (MDCK) cells were maintained in Dulbecco's Modified Eagle's Medium (DMEM) supplemented with $10 \%$ fetal bovine serum, 100 -fold dilution of penicillin-streptomycin solution (HyClone), and $250 \mu \mathrm{g} / \mathrm{mL}$ amphotericin, as used for influenza A virus amplification and plaque assays.

2.2. S. baicalensis Extracts and Indicated Flavonoids. Thirty grams of $S$. baicalensis crude powder (Sun Ten Pharmaceutical Co., Ltd.) were dissolved in $200 \mathrm{~mL}$ ethyl acetate (EtOAc), methanol $(\mathrm{MeOH})$, or chloroform and then gently sonicated $30 \mathrm{~min}$ at room temperature. Extract solutions centrifuged were filtered with Whatman No. 1 filter paper, then lyophilized by the freeze dryer (IWAKI FDR-50P). Each lyophilized extract powder was kept at $-20^{\circ} \mathrm{C}$; stock solutions $(1 \mathrm{mg} / \mathrm{mL})$ dissolved in phosphate-buffered saline and sterilized using a $0.44 \mu \mathrm{m}$ syringe filter were stored at $-80^{\circ} \mathrm{C}$ until used.

2.3. Fingerprint Analysis by HPLC. Baicalein, baicalin, chrysin, and apigenin that were purchased from Sigma Chemical Co. (St. Louis, MO, USA) were used as marker compounds of $S$. baicalensis flavonoids. Fingerprint profiles of $S$. baicalensis extracts were analyzed and compared with retention time of marker compounds, using HITACHI HPLC system (HITACHI, Japan) with quaternary pump (pump L-2130), a UV detector (L-2400), and a Waters XBridge C18 column $(5 \mu \mathrm{m}, 4.6 \times 100 \mathrm{~mm}$, Waters $)$. Mobile phase was performed as the linearly gradient from $100 \%$ acetonitrile to $0.5 \%$ sodium acetate in water during the period of $20 \mathrm{~min}$. Chromatographic separation is set at $1.0 \mathrm{~mL} / \mathrm{min}$ flow rate, elution peaks are detected at $280 \mathrm{~nm}$, and each peak area is autocalculated with a 2996 PDA detector.

2.4. Enzymatic Assay of NA Activity by Fluorometric Substrate. Fluorometric substrate $2^{\prime}$-(4-methylumbelliferyl)- $\alpha$ $\mathrm{D}-\mathrm{N}$-acetylneuraminic acid (MUNANA; Sigma) was used to determine NA activity as described in a prior report [31]. To determine NA activity of pandemic $2009 \mathrm{H1N1}$ and seasonal $2007 \mathrm{H} 1 \mathrm{N1}$ viruses, serial 10-fold dilution of viruses $\left(10^{6} \mathrm{PFU} / \mathrm{mL}\right)$ was added to the wells of a 96 -well plate, mixed with MUNANA solution at final concentration of $300 \mu \mathrm{M}$, and then incubated for $1 \mathrm{~h}$ at $37^{\circ} \mathrm{C}$. Relative NA enzymatic activity was determined as the fluorescent intensity at a $360 \mathrm{~nm}$ excitation and a $460 \mathrm{~nm}$ emission wavelength (Multidetection Fluorescence-Luminescence Microplate Reader). For examining the inhibitory effects of S. baicalensis on NA activity, serial dilution of each extract or flavonoid was preincubated with each subtype of influenza A virus $\left(10^{5} \mathrm{PFU} / \mathrm{mL}\right)$ for $1 \mathrm{~h}$ at $37^{\circ} \mathrm{C}$, and mixture followed to react with MUNANA solution for another hour. Concentration of each extract or flavonoid showing $50 \%$ inhibitory effect $\left(\mathrm{IC}_{50}\right)$ compared to the control with no inhibitor was determined 
by computer program (provided by John Spouge, National Institutes of Health).

2.5. Cytotoxic Assay for Extracts and Flavonoids of S. baicalensis. MDCK cells were cultured in 96-well plates, followed by $48 \mathrm{~h}$ incubation after adding medium containing each S. baicalensis extract $(0,100,200$, or $1000 \mu \mathrm{g} / \mathrm{mL})$, baicalein $(0,0.01,0.1,1$, or $10 \mu \mathrm{M})$, baicalin $(0,0.001,0.01,0.1$, or $1 \mu \mathrm{M})$, apigenin $(0,1,10,100$, or $1000 \mu \mathrm{M})$, or chrysin $(0,1,10,100$, or $1000 \mu \mathrm{M})$. Quintuplicate wells were performed for each concentration. Survival rates of cells were determined by MTT (3-(4,5-Dimethylthiazol-2-yl)-2,5-diphenyltetrazolium bromide) assay. Each well had $5 \mu \mathrm{L}$ of MTT solution $(5 \mathrm{mg} / \mathrm{mL})$ added for another $3 \mathrm{~h}$, incubated, and washed three times with phosphate buffer saline before finally adding $100 \mu \mathrm{L}$ DMSO to wells for dissolving formazan crystals. Cell survival rates were calculated as ratio of optical density $\left(\mathrm{OD}_{570 \mathrm{~nm}}-\mathrm{OD}_{630 \mathrm{~nm}}\right)$ of treated cells to mock cells. Data represent mean $\pm \mathrm{SD}$ of three independent experiments, and concentration giving $50 \%$ cytotoxic effect $\left(\mathrm{CC}_{50}\right)$ was determined by ID50 computer program developed by Dr. John Spouge (National Institutes of Health).

2.6. Plaque Inhibition Assay for Anti-Influenza A Virus Activity of S. baicalensis . Confluent monolayers of MDCK cells in 6-well plates were inoculated with the influenza A virus (100 PFU) and immediately treated with/without $S$. baicalensis extract $(0,10,100$, or $1000 \mu \mathrm{g} / \mathrm{mL})$, baicalein $(0$, $0.001,0.01$, or $0.1 \mu \mathrm{M})$, baicalin $(0,0.001,0.01$, or $0.1 \mu \mathrm{M})$, apigenin $(0,10,100$, or $200 \mu \mathrm{M})$, or chrysin $(0,10,100$, or $200 \mu \mathrm{M})$. After $1 \mathrm{~h}$ absorption at $33^{\circ} \mathrm{C}$, cells were overlaid with maintenance DMEM medium containing $1 \%$ agarose, $0.2 \%$ serum albumin, and $2.5 \mu \mathrm{g} / \mathrm{mL}$ of trypsin. After 3 days of incubation at $33^{\circ} \mathrm{C}$ in a humidified atmosphere of $5 \% \mathrm{CO}_{2}$, cells were stained with $0.1 \%$ crystal violet in $37 \%$ formaldehyde solution. Concentration giving 50\% plaque inhibition $\left(\mathrm{IC}_{50}\right)$ was determined, using ID50 computer program.

2.7. Cytopathic Effect, Virus Yield, and Time-of-Addition Assays. S. baicalensis extract $(0,10,100$, or $1000 \mu \mathrm{g} / \mathrm{mL})$, baicalein $(0,0.001,0.01$, or $0.1 \mu \mathrm{M})$, baicalin $(0,0.001,0.01$, or $0.1 \mu \mathrm{M})$, apigenin $(0,10,100$, or $200 \mu \mathrm{M})$, or chrysin $(0,10,100$, or $200 \mu \mathrm{M})$ was added to MDCK cells cultured in 6-well plates during (simultaneous treatment) and $1 \mathrm{~h}$ after (postinfection treatment) infection with pandemic 2009 H1N1 at MOI 1. Thirty-six h after infection, virusinduced cytopathic effect in each well was photographed using reverse-phase light microscopy; viral RNA genome in each cultured supernatant was extracted by QIAamp Viral RNA Mini Kit (Qiagen). Real-time RT-PCR was performed with specific primers for pandemic $2009 \mathrm{H} 1 \mathrm{N1}$ (Supplemental Table 1), SYBR green PCR Master Mix, and SYBR Green I dsDNA binding dye by ABI PRISM 7000 sequence detection system (Applied Biosystems). $\Delta C_{t}$ value as relative viral RNA load was calculated by subtracting $C_{t}$ value for viral load in cultured media of treated infected cells from $C_{t}$ value in those of mock-infected cells. $\Delta C_{t}$ value above 3.3 indicated more than 1-log reduction (equal to $90 \%$ inhibitory concentration $\left(\mathrm{IC}_{90}\right)$ ) in virus RNA load.

2.8. Molecular Docking. The crystal structures of neuraminidase NA1 (PDB: 3cl0), NA2 (PDB: 4gzp), and NA9 (PDB: 3nn9) deposited in the RCSB Protein Data Bank (http://www.rcsb.org/pdb) were used as the targets for molecular docking. The docking calculations of S. baicalensis flavonoids and Tamiflu with NA1, NA2, and NA9 were performed with LigandFit program within the software package Discovery Studio 2.5 (Accelrys, San Diego, USA), which is an automated tool for ligand-protein docking and scoring. The prepared protein protocol was used to NA structures including the following actions: standardize atom names, insert missing atoms in residues and remove alternate conformations, insert missing loop regions based on SEQRES data, optimize short and medium size loop regions with Looper algorithm, minimize remaining loop regions, and calculate $\mathrm{p} K$ and protonate structure.

\section{Results}

3.1. Inhibition of NA Activity by S. baicalensis Extracts. To screen inhibitory effects of $S$. baicalensis extracts on NA enzymatic activity, fluorometric activity assay of NA with MUNANA substrate indicated NA enzymatic activity of pandemic 2009 and seasonal 2007 H1N1 influenza A viruses by virus titer-dependent manner (Figure 1). Meanwhile, pandemic $2009 \mathrm{H} 1 \mathrm{~N} 1$ influenza A virus exhibited greater NA activity than seasonal $2007 \mathrm{H} 1 \mathrm{N1}$ influenza A virus. Subsequently, $\mathrm{MeOH}, \mathrm{EtOAc}$, and chloroform extracts of $S$. baicalensis were prepared to test their inhibitory effects on NA activity of five variants: pandemic $2009 \mathrm{H} 1 \mathrm{~N} 1$, seasonal 2007 H1N1, 2009 H1N1, 2009 H3N2, and PR8 H1N1 influenza A viruses (Table 1). EtOAc and chloroform extract inhibited NA enzymatic activity of these variants more potently than $\mathrm{MeOH}$ extract. Ranking $\mathrm{IC}_{50}$ value of EtOAc extract on inhibiting NA activity of the variants from lowest to highest saw seasonal $2007 \mathrm{H} 1 \mathrm{~N} 1(73.16 \mu \mathrm{g} / \mathrm{mL}), 2009 \mathrm{H} 1 \mathrm{~N} 1$ $(176.57 \mu \mathrm{g} / \mathrm{mL}), 2009 \mathrm{H} 3 \mathrm{~N} 2(306.96 \mu \mathrm{g} / \mathrm{mL})$, pandemic 2009 H1N1 $(388.98 \mu \mathrm{g} / \mathrm{mL})$, and PR8 H1N1 influenza A viruses $(487.40 \mu \mathrm{g} / \mathrm{mL})($ Table 1$)$. Therefore, S. baicalensis extracts as NA inhibitors further examined inhibitory effect on replication of influenza A viruses.

3.2. Inhibition of Influenza A Virus Replication by S. baicalensis Extracts. Cytotoxicity of S. baicalensis extract to MDCK cells was examined by MTT assay (Table 2); these extracts proved less toxic $\left(\mathrm{CC}_{50} \geq 800 \mu \mathrm{g} / \mathrm{mL}\right)$ as available for in vitro activity against influenza A viruses. Plaque inhibition assay indicated S. baicalensis extracts concentration dependently inhibiting replication of pandemic $2009 \mathrm{H} 1 \mathrm{~N} 1$ and seasonal 2007 H1N1 influenza A viruses (Table 2). IC $_{50}$ values against seasonal $2007 \mathrm{H} 1 \mathrm{~N} 1$ influenza A virus were $23.7 \mu \mathrm{g} / \mathrm{mL}$ for EtOAc extract and $41.5 \mu \mathrm{g} / \mathrm{mL}$ for chloroform extract; $\mathrm{IC}_{50}$ values against pandemic $2009 \mathrm{H} 1 \mathrm{~N} 1$ influenza A virus were $27.4 \mu \mathrm{g} / \mathrm{mL}$ for EtOAc extract and $14.2 \mu \mathrm{g} / \mathrm{mL}$ for chloroform extract, respectively, and therapeutic indexes above 30 against 
TABLE 1: Inhibitory effects of MeOH, EtOAc, and chloroform extracts of S. baicalensis on NA enzymatic activity.

\begin{tabular}{|c|c|c|c|c|c|}
\hline \multirow{2}{*}{ Extract } & \multicolumn{5}{|c|}{ NA inhibition $\mathrm{IC}_{50}$ values $(\mu \mathrm{g} / \mathrm{mL})$} \\
\hline & Seasonal $2007 \mathrm{H} 1 \mathrm{~N} 1$ & Pandemic 2009 H1N1 & PR8 H1N1 & Seasonal $2009 \mathrm{H} 1 \mathrm{~N} 1$ & Seasonal $2009 \mathrm{H} 3 \mathrm{~N} 2$ \\
\hline $\mathrm{MeOH}$ & $613.94 \pm 5.54$ & $>1000$ & $>1000$ & $875.92 \pm 1.01$ & $783.31 \pm 0.23$ \\
\hline EtOAc & $73.17 \pm 1.65$ & $388.98 \pm 0.93$ & $487.40 \pm 1.68$ & $176.57 \pm 0.32$ & $306.96 \pm 0.40$ \\
\hline Chloroform & $109.71 \pm 3.08$ & $562.94 \pm 0.78$ & $569.20 \pm 0.52$ & $251.29 \pm 2.30$ & $427.55 \pm 0.59$ \\
\hline
\end{tabular}

TABLE 2: Plaque reduction of influenza A virus by MeOH, EtOAc, and chloroform extracts of S. baicalensis.

\begin{tabular}{lccccc}
\hline \multirow{2}{*}{ Extracts } & $\mathrm{CC}_{50}(\mu \mathrm{g} / \mathrm{mL})$ & \multicolumn{2}{c}{ Plaque inhibition $\mathrm{IC}_{50}$ values $(\mu \mathrm{g} / \mathrm{mL})$} & \multicolumn{3}{c}{ Therapeutic index } \\
& MDCK cells & Seasonal 2007 H1N1 & Pandemic 2009 H1N1 & Seasonal 2007 H1N1 & Pandemic 2009 H1N1 \\
\hline MeOH & $923.12 \pm 0.017$ & $134.22 \pm 0.059$ & $28.24 \pm 0.049$ & 6.9 & 32.7 \\
EtOAc & $836.24 \pm 0.023$ & $23.70 \pm 0.053$ & $27.39 \pm 0.049$ & 35.3 & 30.5 \\
Chloroform & $829.77 \pm 0.009$ & $41.49 \pm 0.052$ & $14.16 \pm 0.083$ & 20.0 & 58.6 \\
\hline
\end{tabular}

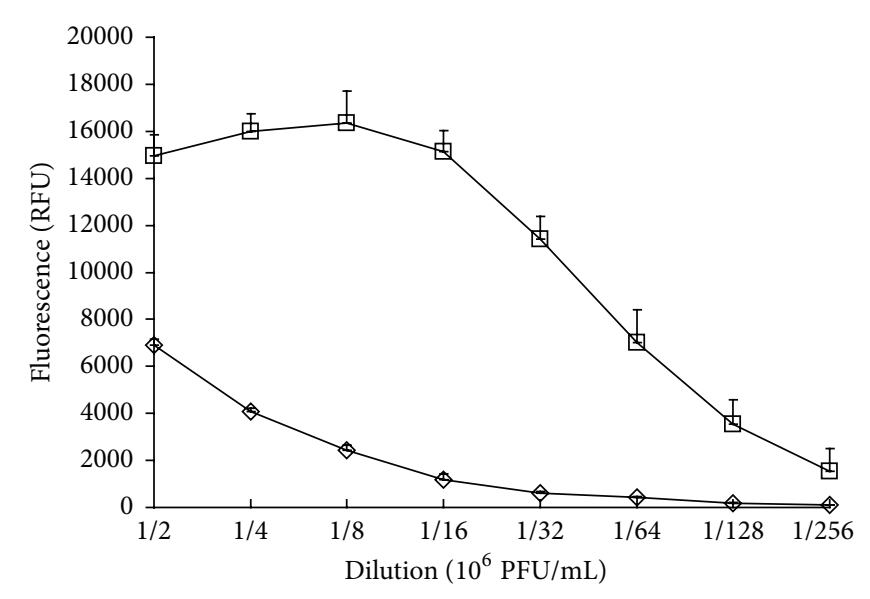

$\diamond$ Seasonal influenza A/Taiwan/CMUH/2007 (H1N1)
$\square$ Pandemic influenza A/Taiwan/CMUH/2009 (H1N1)

FIGURE 1: In vitro NA enzymatic activity of pandemic $2009 \mathrm{H} 1 \mathrm{~N} 1$ and seasonal $2007 \mathrm{H} 1 \mathrm{N1}$ influenza A viruses. Fluorometric substrate MUNANA $(300 \mu \mathrm{M})$ was incubated with serial 10-fold dilution of viruses $\left(10^{6} \mathrm{PFU} / \mathrm{mL}\right)$ and then incubated for $1 \mathrm{~h}$ at $37^{\circ} \mathrm{C}$. Relative NA enzymatic activity was determined as the fluorescent intensity at a $360 \mathrm{~nm}$ excitation and a $460 \mathrm{~nm}$ emission wavelength.

both pandemic $2009 \mathrm{H} 1 \mathrm{~N} 1$ and seasonal $2007 \mathrm{H} 1 \mathrm{~N} 1$ influenza A viruses.

3.3. Inhibition of Pandemic 2009 H1N1 Influenza A Virus Yield by Time-of-Addition with S. baicalensis Extracts. To examine time-of-addition effect on virus yield, MDCK cells were treated simultaneously (at the same time as infection) or after infection (after entry) with various concentrations of $S$. baicalensis extracts. EtOAc and chloroform extracts, but not $\mathrm{MeOH}$ extract, showing concentration-dependent inhibition of cytopathic effect as well as virus yield with simultaneous and postinfection treatment (Figure 2). Real-time RT-PCR assay indicated simultaneous and postinfection treatment of EtOAc and chloroform extract $(100 \mu \mathrm{g} / \mathrm{mL})$ causing more than $1-\log$ reduction in virus RNA loads $\left(\Delta C_{t}\right.$ value greater than 3.3) compared to mock-infected supernatant.
3.4. HPLC Analysis of Flavonoids in S. baicalensis Extracts. S. baicalensis contains more than 200 compounds identified with over 40 flavonoids. Six major bioactive flavonoids in S. baicalensis are baicalein, baicalin, wogonin, wogonside, oroxylin, and oroxylin A-7-glucuronide; minor bioactive flavonoids have chrysin, chrysin-6,8-di-C-glucoside, apigenin, apigenin-6-C-glucose-8-C-arabinose, and so forth [23]. To examine fingerprint of $S$. baicalensis extracts, baicalein, baicalin, apigenin, and chrysin were used as standard marker components; these three extracts were analyzed using HPLC with C-18 reverse phase column (Figure 3). The retention time of HLPC chromatograph at $280 \mathrm{~nm}$ was at $8.20 \mathrm{~min}$ for baicalin, $11.10 \mathrm{~min}$ for apigenin, $12.40 \mathrm{~min}$ for baicalein, and $13.10 \mathrm{~min}$ for chrysin, respectively. HPLC chromatogram indicated that the concentrations of baicalin, apigenin, baicalein, and chrysin were $29.68 \%, 0.09 \%, 7.48 \%$, and $4.44 \%$ in the $\mathrm{MeOH}$ extract (Figure 3(a)), 3.30\%, $14.23 \%$, $14.04 \%$, and $17.76 \%$ in the EtOAc extract (Figure 3(b)), and $0.47 \%, 0.74 \%, 25.30 \%$, and $18.30 \%$ in the chloroform extract (Figure 3(c)), respectively. In addition to these four makers used, HPLC chromatogram demonstrated other components in each extract. For analyzing the association of relative concentrations of flavonoids with antiviral activities of different extracts, baicalein, baicalin, apigenin, and chrysin against influenza A viruses were further rated by molecular docking with NA, NA enzymatic inhibition, and plaque reduction assays (Tables 3-6, Figure 4).

3.5. Molecular Interaction of S. baicalensis Flavonoids with $N A 1, N A 2$, and NA9. In order to predict the vital antiviral components of $S$. baicalensis EtOAc and chloroform extracts, the computational simulation of $S$. baicalensis flavonoids such as baicalein, baicalin, apigenin, and chrysin, with influenza A viruses NA1, NA2, and NA9, was performed. We scored our models using two scoring functions, LigScore and DockScore, and in addition, Tamiflu was used as a positive control in this docking experiment. The results showed that the $S$. baicalensis flavonoids, especially baicalin and baicalein, bond well to NA1, NA2, and NA9, with the high affinity based on higher score values using LigScore2_Dreiding and DockScore programs (Table 4). As shown in Table 4 and 
TABLE 3: Molecular docking of S. baicalensis flavonoids into influenza A viruses NA1, NA2, and NA9.

\begin{tabular}{|c|c|c|c|c|c|c|}
\hline \multirow{2}{*}{ Flavonoids } & \multicolumn{3}{|c|}{ LigScore2_Dreiding } & \multicolumn{3}{|c|}{ DockScore } \\
\hline & $\mathrm{NAl}^{\mathrm{a}}$ & $\mathrm{NA} 2^{\mathrm{b}}$ & $\mathrm{NA9}^{\mathrm{c}}$ & $\mathrm{NA1}^{\mathrm{a}}$ & $\mathrm{NA} 2^{\mathrm{b}}$ & NA9 ${ }^{c}$ \\
\hline Baicalein & 4.42 & 3.76 & 4.68 & 61.041 & 49.358 & 36.683 \\
\hline Baicalin & 6.52 & 4.13 & 5.24 & 77.712 & 48.391 & 38.279 \\
\hline Apigenin & 4.51 & 3.66 & 4.41 & 57.727 & 44.794 & 35.018 \\
\hline Chrysin & 4.92 & 3.64 & 4.37 & 54.621 & 40.560 & 34.109 \\
\hline Tamiflu & 5.67 & 3.67 & 4.16 & 54.409 & 33.117 & 33.935 \\
\hline
\end{tabular}

${ }^{a}$ Avian influenza virus A/Vietnam/1203/04 (H5N1).

${ }^{\mathrm{b}}$ Influenza virus A/Tanzania/205/2010 (H3N2).

${ }^{c}$ Avian influenza virus A/tern/Australia/G70c/75 (N9).

TABLE 4: Key interactions of $S$. baicalensis flavonoids with NA1 active sites.

Flavonoids
Baicalein

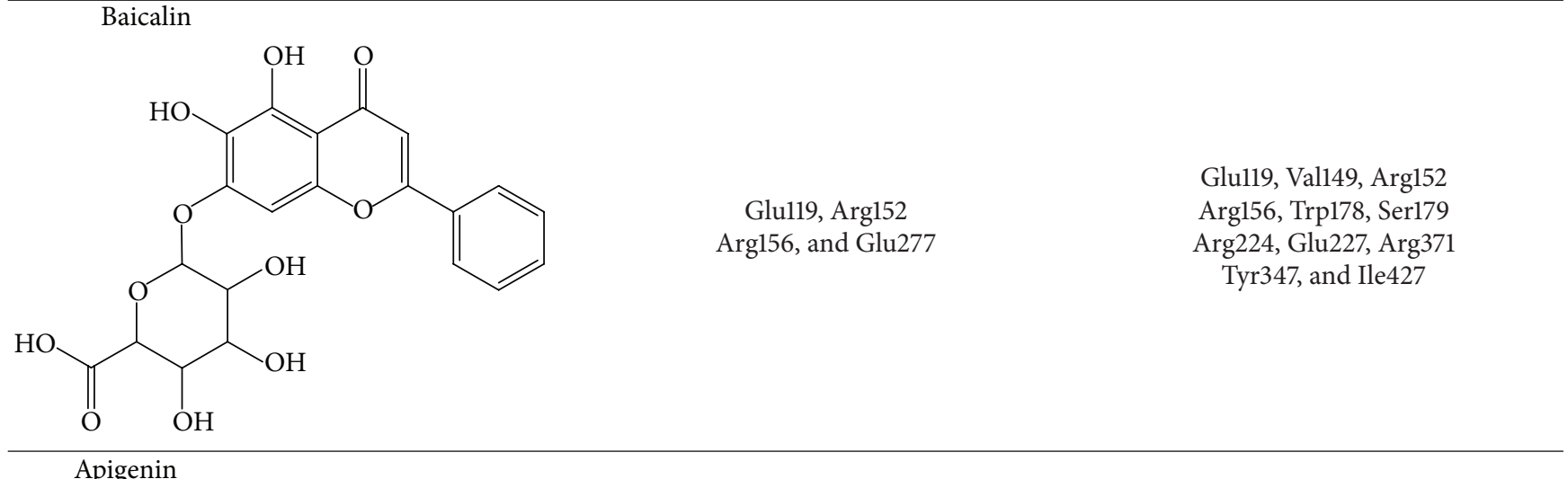

$\begin{gathered}\text { Arg118, Val149, Asp151 246, Tyr 274, Glu276 } \\ \text { Arg292, Arg371, and Tyr406 } \\ \text { Arger }\end{gathered}$
$\begin{gathered}\text { Arg118, Asp151 } \\ \text { Glu276, and Arg371 }\end{gathered}$
Arg118, Glu119, Glu227
Glu277, Arg292, and Arg371
Pro431




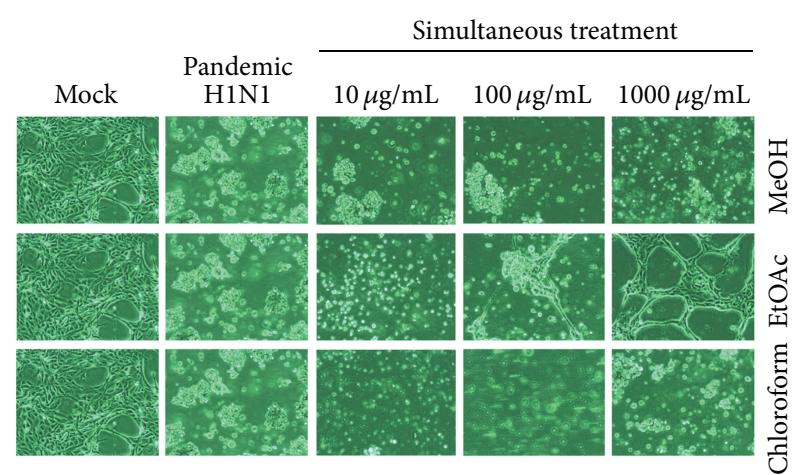

(a)

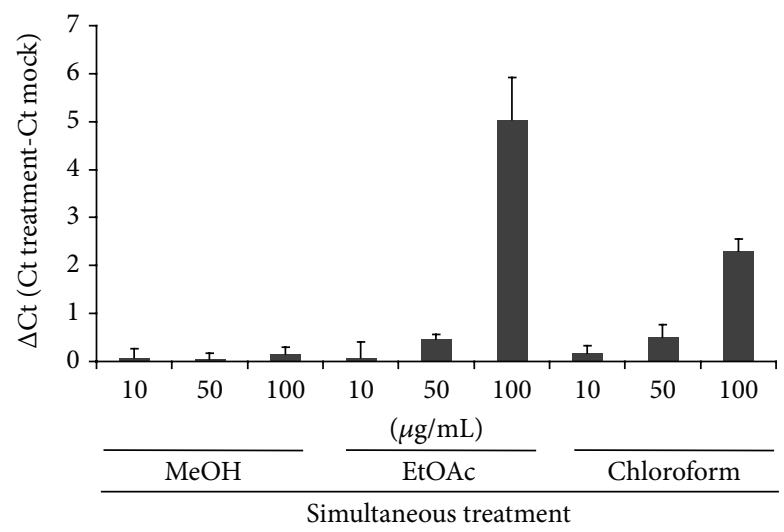

(c)

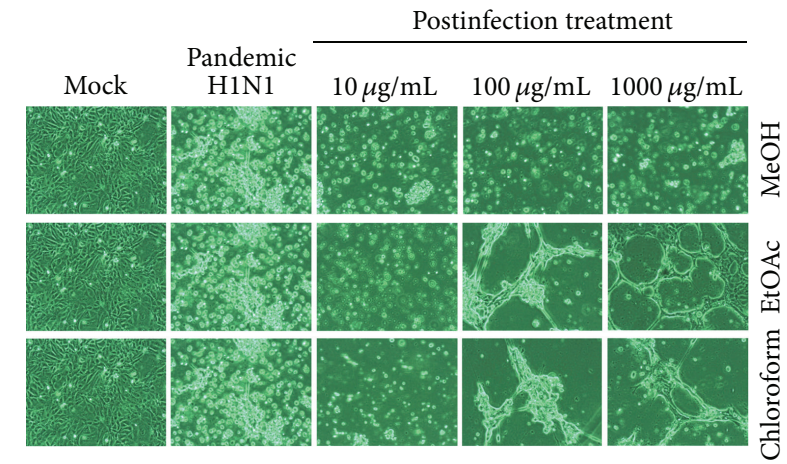

(b)

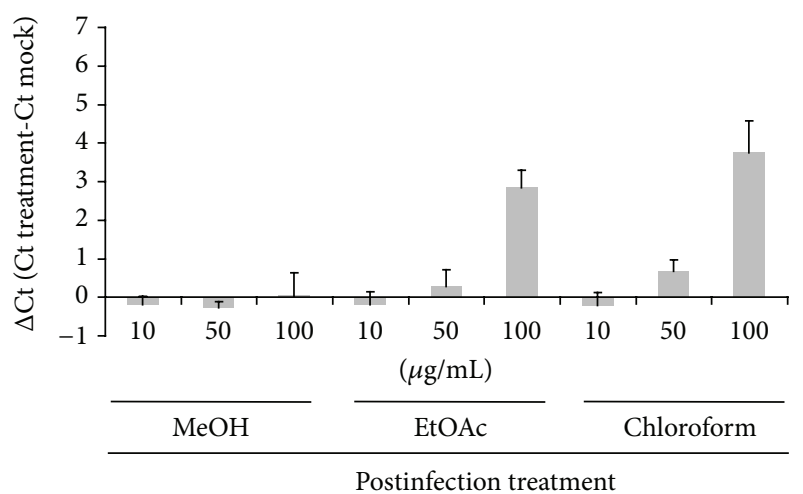

(d)

FiguRE 2: Time-of-addition inhibition of S. baicalensis extracts on pandemic $2009 \mathrm{H} 1 \mathrm{N1}$ influenza A virus yields. Indicated extracts (0, 10, 100, or $1000 \mu \mathrm{g} / \mathrm{mL}$ ) treated MDCK cells during (simultaneous treatment) (a) and $1 \mathrm{~h}$ after (postinfection treatment) (b) infections of pandemic $2009 \mathrm{H} 1 \mathrm{~N} 1$ virus. After $36 \mathrm{~h}$ incubation, virus-induced cytopathic effect was photographed, using reverse-phase light microscopy. (c and d) Virus yield was determined real-time RT-PCR; $\Delta C_{t}$ value was calculated by subtracting $C_{t}$ value for viral load in cultured media of treated infected cells from $C_{t}$ value in those of mock-infected cells.

TABLE 5: Inhibitory effects of flavonoids of S. baicalensis on NA enzymatic activity.

\begin{tabular}{lccccc}
\hline \multirow{2}{*}{ Flavonoids } & & \multicolumn{4}{c}{ NA inhibition $\mathrm{IC}_{50}$ values $(\mu \mathrm{M})$} \\
& Seasonal 2007 H1N1 & Pandemic 2009 H1N1 & PR8 H1N1 & Seasonal 2009 H1N1 & Seasonal 2009 H3N2 \\
\hline Baicalein & $0.423 \pm 0.069$ & $0.287 \pm 0.074$ & 0.181 & $0.526 \pm 0.084$ & 0.436 \\
Baicalin & $2.55 \pm 0.083$ & $2.57 \pm 0.077$ & 2.754 & $5.84 \pm 0.074$ & 3.98 \\
Apigenin & 61.72 & 112.23 & 81.3 & $118.48 \pm 0.06$ & 83 \\
Chrysin & 109.64 & $465.11 \pm 0.09$ & 131.92 & $175.43 \pm 0.70$ & 194.93 \\
\hline
\end{tabular}

Figure 4(a), baicalein interacted with Ile222, Arg224, Ser246, Glu277, and Tyr347 in Pocket I and II of NA1 (PDB: 3cl0) via hydrogen bonding and Van der Waals interactions. Interaction of baicalin with NA1 showed five hydrogen bonds between baicalin and Glu119, Arg152, Arg156, and Glu277 as well as Van der Waals interactions between the ligand and Glu119, Val149, Arg152, Arg156, Trp178, Ser179, Arg224, Glu227, Arg371, Tyr347, and Ile427 in Pocket I and III of NA1 (Figure 4(b) and Table 4). As to the simulation of apigenin or chrysin with NA1 (Figures 4(c) and 4(d)), hydrogen bonds and Van der Waals interactions were present between the ligand and the residues in Pocket I and III of NA1. These interactions showed baicalein directly interacting with the hydrophobic pocket (Pocket II) formed by highly conserved residues of NA, but baicalin, apigenin, or chrysin hydrogen bonding with the charge residues in Pocket III of NA1. The results indicated these four flavonoids directly interacting with NA1 active-site residues; baicalein showed the unique interaction with NA1, particularly via hydrophobic interactions with Ile222, Arg224, and Ser246.

3.6. NA Inhibition and Plaque Reduction by S. baicalensis Flavonoids. Flavonoids baicalein, baicalin, apigenin, and chrysin were further tested for inhibitory ability of NA enzymatic activity, using fluorometric assay (Table 5). $\mathrm{IC}_{50}$ NA inhibition values against five variants were $0.18 \sim 0.53 \mu \mathrm{M}$ for baicalein, $2.55 \sim 5.84 \mu \mathrm{M}$ for baicalin, $61.7 \sim 118.48 \mu \mathrm{M}$ 


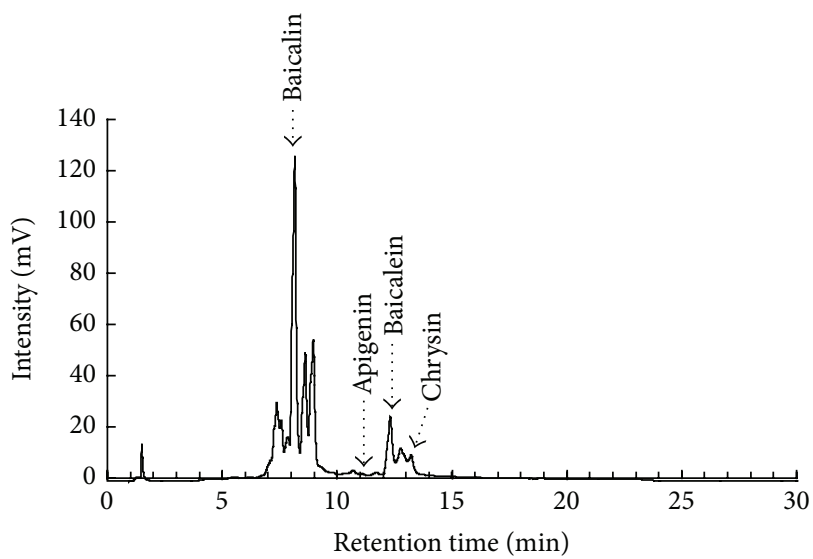

(a)

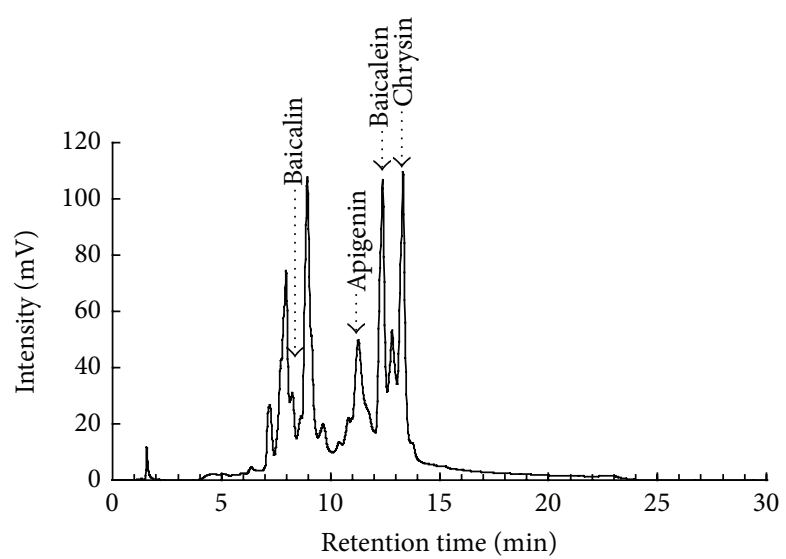

(b)

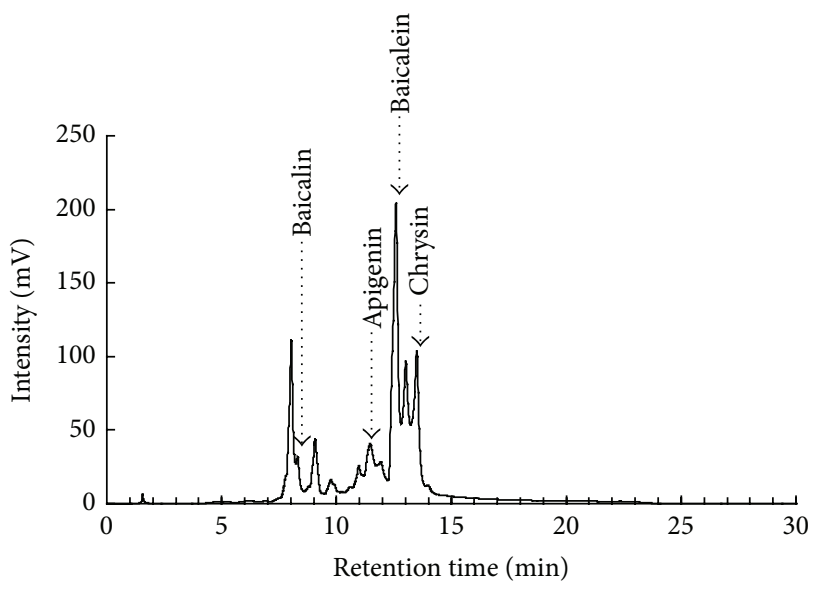

(c)

FIGURE 3: HPLC fingerprint profiles of S. baicalensis extracts. Marker components (baicalein, baicalin, apigenin, and chrysin), as well as the $\mathrm{MeOH}(\mathrm{a}), \mathrm{EtOAc}(\mathrm{b})$, and chloroform (c) extracts, were analyzed by HPLC with C-18 reverse phase column, and eluents are detected at 280 nm with a 2996 PDA detector.

TABLE 6: Plaque reduction of influenza A virus by flavonoids of S. baicalensis.

\begin{tabular}{lccccc}
\hline \multirow{2}{*}{ Flavonoids } & $\mathrm{CC}_{50}(\mu \mathrm{M})$ & \multicolumn{2}{c}{ Plaque inhibition $\mathrm{IC}_{50}$ values $(\mu \mathrm{M})$} & \multicolumn{2}{c}{ Therapeutic index } \\
& MDCK cells & Seasonal 2007 H1N1 & Pandemic 2009 H1N1 & Seasonal 2007 H1N1 & Pandemic 2009 H1N1 \\
\hline Baicalein & $0.045 \pm 0.088$ & $0.018 \pm 0.062$ & $0.020 \pm 0.077$ & 2.5 & 2.3 \\
Baicalin & 0.015 & $>0.01$ & $>0.01$ & 1.8 & 2.3 \\
Apigenin & $218.34 \pm 0.11$ & $119.61 \pm 0.032$ & $94.16 \pm 0.047$ & & \\
Chrysin & $266.66 \pm 0.077$ & $>200$ & $>200$ & \\
\hline
\end{tabular}

for apigenin, and $109.64 \sim 465.11 \mu \mathrm{M}$ for chrysin, respectively. In plaque reduction assay, these flavonoids exhibited concentration-dependent inhibitory effect. In particular, $\mathrm{IC}_{50}$ plaque reduction values of baicalein were $0.018 \mu \mathrm{M}$ against seasonal $2007 \mathrm{H} 1 \mathrm{~N} 1$ influenza $\mathrm{A}$ virus and $0.02 \mu \mathrm{M}$ against pandemic $2009 \mathrm{H} 1 \mathrm{N1}$ influenza A virus (Table 6). Of them, only baicalein showed therapeutic index greater than $2\left(\mathrm{CC}_{50} / \mathrm{IC}_{50}\right.$ plaque reduction) against both variants. Interestingly, virus yield assay with real-time PCR indicated these flavonoids with higher antiviral activity after infection than simultaneous treatment (Figure 5).

\section{Discussion}

This study demonstrated different NA enzymatic activity of influenza A subtypes as well as high NA activity of pandemic 2009 H1N1 influenza A virus and low NA activity of seasonal 2007 H1N1 influenza A virus (Figure 1), correlating with in vitro NA sensitivity to $S$. baicalensis extracts (Table 1 ). $\mathrm{IC}_{50}$ values against pandemic $2009 \mathrm{H} 1 \mathrm{~N} 1$ influenza A virus by EtOAc $(388.98 \mu \mathrm{g} / \mathrm{mL})$ and chloroform $(562.94 \mu \mathrm{g} / \mathrm{mL})$ extracts were higher than $\mathrm{IC}_{50}$ values against seasonal 2007 $\mathrm{H} 1 \mathrm{~N} 1$ influenza A virus (73.17 and $109.71 \mu \mathrm{g} / \mathrm{mL}$, resp.); EtOAc 


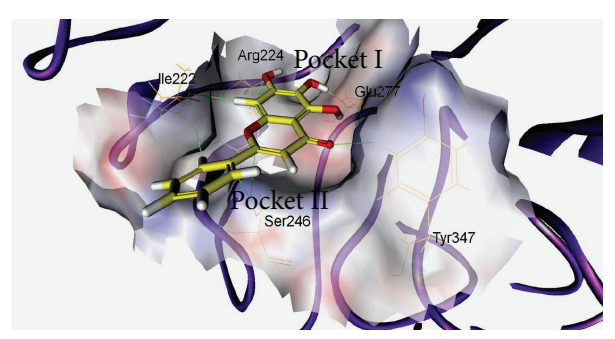

(a)

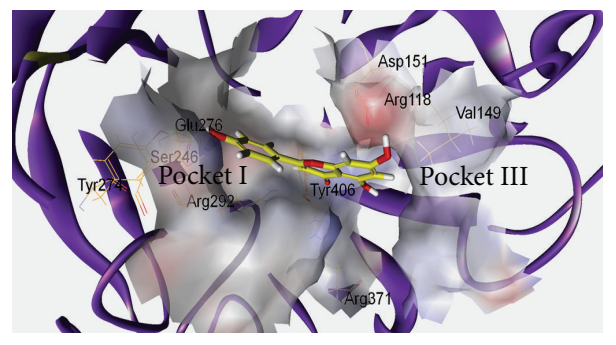

(c)

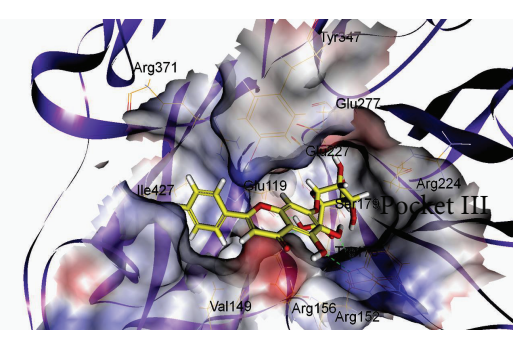

(b)

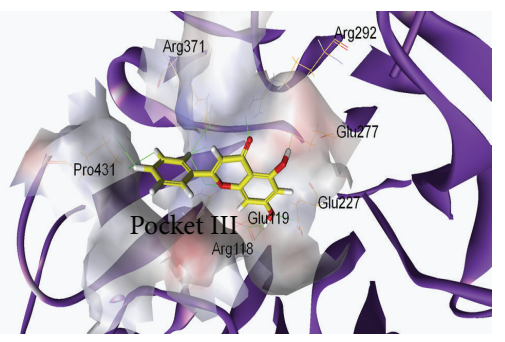

(d)

FIGURE 4: Molecular modeling. Baicalein (a), baicalin (b), apigenin (c), and chrysin (d) docked well with NA1 active sites. The binding amino acids are shown as lines and labels. The carved surface representation of the pocket formed from flavonoid binding is shown as transparent gray.

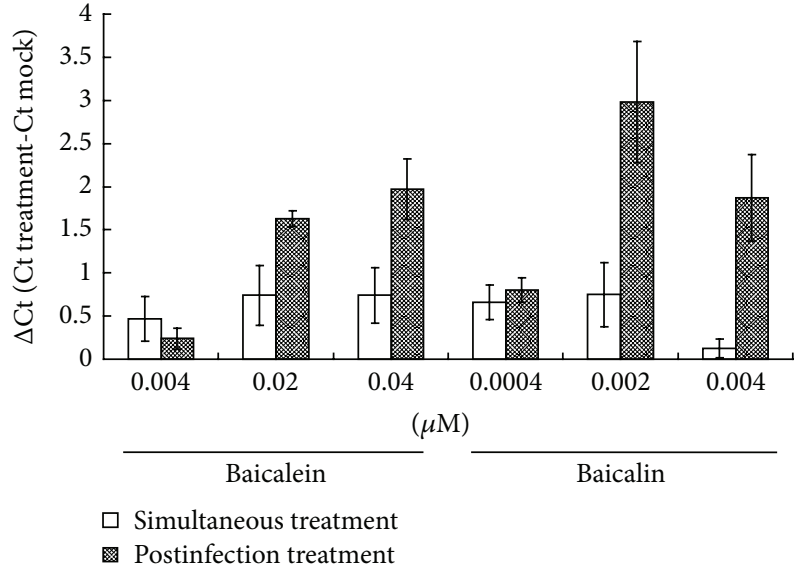

(a)

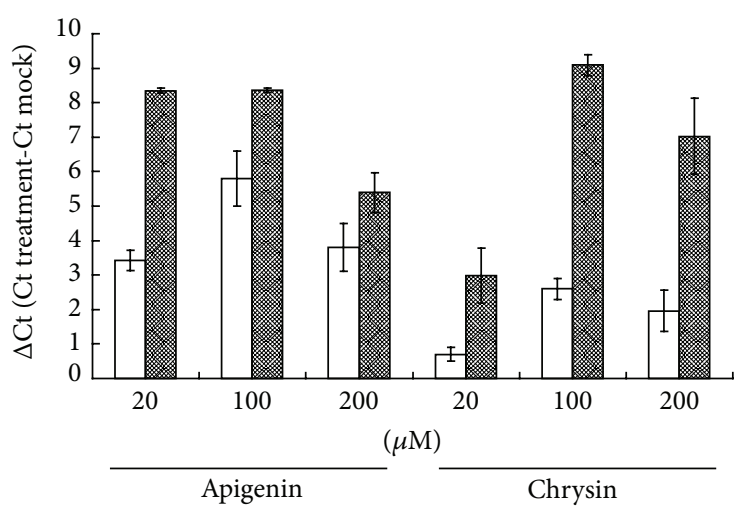

$\square$ Simultaneous treatment $\square$ Postinfection treatment

(b)

Figure 5: Time-of-addition inhibition of S. baicalensis flavonoids on pandemic 2009 H1N1 virus yields. Baicalein, baicalin (a), apigenin, or chrysin (b) was incubated with MDCK cells during (simultaneous treatment) and $1 \mathrm{~h}$ after (postinfection treatment) infections of pandemic $2009 \mathrm{H} 1 \mathrm{N1}$ influenza A virus. Virus yield was determined real-time RT-PCR; $\Delta C_{t}$ value was calculated by subtracting $C_{t}$ value for viral load in cultured media of treated infected cells from $C_{t}$ value in those of mock-infected cells.

and chloroform extracts showed higher NA inhibitory ability with lower $\mathrm{IC}_{50}$ values against these variants compared to $\mathrm{MeOH}$ extract. Interestingly, the plaque reduction assay indicated EtOAc and chloroform extracts as lower $\mathrm{IC}_{50}$ plaque inhibition values than $\mathrm{IC}_{50} \mathrm{NA}$ inhibition values against pandemic $2009 \mathrm{H} 1 \mathrm{~N} 1$ and seasonal $2007 \mathrm{H} 1 \mathrm{~N} 1$ influenza A viruses (Table 2). Time-of-addition assay revealed EtOAc and chloroform extracts reducing virus yield significantly in both simultaneous and postinfection treatment assays (Figure 2), also attesting to therapeutic potential of EtOAc and chloroform extracts against influenza A. These revealed EtOAc and chloroform extracts with multiple anti-influenza A virus actions, except for NA inhibition.
Over 30 flavonoids were identified from S. baicalensis, being linked with the antiviral activity of EtOAc and chloroform extracts. As shown in Figure 3, the retention time order of these four flavonoids in reverse phase C18 column was chrysin $(13.10 \mathrm{~min})>$ baicalein $(12.40 \mathrm{~min})>$ apigenin $(11.10 \mathrm{~min})>$ baicalin $(8.20 \mathrm{~min})$, being in accordance with the prior study [32]. Meanwhile, glycoside forms like baicalin, wogonside, and roxylin A-7-glucuronide of flavonoids in $S$. baicalensis were rich in the methanol extract, while aglycone forms such as baicalein and wogonin were identified in the ethyl acetate extract [33]. Both baicalein and chrysin were rich in EtOAc and chloroform extracts, being involved in antiviral actions of these two extracts against influenza 
A viruses. In vitro antiviral assays indicated baicalein as a potent NA inhibitor with NA inhibition $\mathrm{IC}_{50}$ less than $0.5 \mu \mathrm{M}$ (Table 5), significantly inhibiting the replication of influenza A viruses in cell cultures (plaque reduction $\mathrm{IC}_{50}$ less than $0.05 \mu \mathrm{M}$ ) (Table 6).

Molecular modeling was initially used to predict the interaction of NA with $S$. baicalensis flavonoids, implying the correlation with the inhibitory activity of $S$. baicalensis extracts. Using LigScore2_Dreiding and DockScore elucidated molecular interactions between flavonoids and NA active sites such as hydrogen bonding, Van der Waals, lipophilic, and polar attractive/repulsive interactions. Ranking the docking scores of flavonoids by LigScore2_Dreiding and DockScore was baicalin $>$ baicalein $>$ apigenin $>$ chrysin (Table 3). Table 4 and Figure 4 revealed, these four flavonoids binding with NA active sites, consisting of catalytic sites (Arg118, Asp151, Arg152, Arg224, Glu276, Arg292, Arg371, and Tyr406 in N2 numbering) and substrate binding and framework sites (Glu119, Arg156, Trp178, Ser179, Asp/Asn198, Ile222, Glu227, His274, Glu277, Asn294, and Glu425) [34]. Molecular modeling of baicalin/NA1 complex showed five hydrogen bonds between the ligand and Glu119, Arg152, Arg156, and Glu277 as well as Van der Waals interactions between the ligand and Glu119, Val149, Arg152, Arg156, Trp178, Ser179, Arg224, Glu227, Arg371, Tyr347, and Ile427. Meanwhile, molecular interaction between baicalein and NA1 had one hydrogen bond between the ligand and Glu277 as well as hydrophobic and Van der Waals interactions between the ligand and Ile222, Arg224, Ser246, Glu277, and Tyr347. The difference in the interactions of baicalein and baicalin with NA1 could correlate with more hydrophilic characters of baicalin with three hydroxyl groups and Dglucopyranosiduronic acid compared to baicalein. The reason could be responsible for the correlations between docking scoring and the antiviral activities of these four flavonoids in NA enzymatic inhibition and plaque reduction assays (Tables 5 and 6), in which the order of inhibitory efficacy and antiviral activity was baicalein $>$ baicalin $>$ apigenin $>$ chrysin. The results suggested that the hydrophobic interaction of potential inhibitors with the highly conserved Pocket II (Ile222, Arg224, and Ser246) of NA1 provides the alternative approach to treat the NA inhibitor-resistant mutants such as His274Tyr, Glu119Val, and Arg292Lys mutation in NA1, NA2, and NA9.

Of four S. baicalensis associated flavonoids used in this study, baicalein showed potent anti-influenza A virus activities with $\mathrm{IC}_{50} \mathrm{NA}$ inhibition values ranging from 0.181 to $0.526 \mu \mathrm{M}$ and $\mathrm{IC}_{50}$ plaque reduction values ranging from 0.018 to $0.020 \mu \mathrm{M}$ (Tables 5 and 6 ). Baicalin also had potent anti-influenza $\mathrm{A}$ virus activities with $\mathrm{IC}_{50}$ ranging from 2.55 to $5.84 \mu \mathrm{M}$. Apigenin and chrysin displayed moderate inhibitory effects against influenza A variants. In time-ofaddition assay, postinfection treatment with these flavonoids had more potent inhibitory effect on virus yield compared to simultaneous treatment, linking with their NA inhibition activity and reduction of virus release into cultured supernatant. Baicalein exhibited a broad spectrum of antiviral activities, for example, dengue [35], influenza A H5N1 [36], Sendai [24], and human cytomegalovirus [37]. Baicalein inhibited NA activity of influenza A H5N1 and Sendai viruses
$[24,36]$, echoing our finding NA inhibition by baicalein on pandemic $2009 \mathrm{H} 1 \mathrm{~N} 1$ influenza A virus plus another four variants. Likewise, baicalein suppressed IL-6 and IL8 production in $\mathrm{H} 5 \mathrm{~N} 1$-infected human monocyte-derived macrophages [36]. Aside from baicalein, baicalin manifested antiviral activity against influenza A/FM1/1/47 (H1N1) [25], HIV-1 [38], SARS coronavirus [26], and herpes simplex virus type 1 [39]. Baicalein inhibited Env protein-mediated fusion with chemokine receptors and CD4 during HIV1 entry process [38]. Although the literature survey and our results indicated baicalein and baicalin exhibiting the potent anti-influenza and anti-inflammatory activities, both had low therapeutic index. A combination of baicalein with ribavirin demonstrated synergistic effects on inhibiting in vitro and in vivo replication of influenza A virus [40]. A combined treatment of baicalein/baicalin with other active agents could reduce cytotoxicity with lowering dosage of baicalein/baicalin and prove the anti-influenza potency.

S. baicalensis extracts contain many flavonoids, exhibiting a broad spectrum of antiviral activities, but processing different molecular mechanisms against viral infections. Except for these four flavonoids tested in this study, 5,7,4 ${ }^{\prime}$-trihydroxy-8methoxyflavone and 5,7,8,4' -tetrahydroxyflavone have been identified as $S$. baicalensis-associated flavonoids, exhibiting potent anti-influenza efficacy via inhibiting NA enzymatic activity [41-43]. S. baicalensis extracts suppressed HBV core gene promoter activity and led to inhibited virus production in vitro [44]. S. baicalensis extracts also modulated cytokine production of human peripheral blood leukocytes and then enhanced resistance of host cells to vesicular stomatitis virus infection [22]. Baicalein and wogonin reduced inflammation via suppressing cyclooxygenase-2 activity [45]. Regulation of inflammation, transcriptional activity, and cytokine production could associate with anti-influenza A virus activity of $S$. baicalensis extracts; we will further investigate in detail.

S. baicalensis EtOAc and chloroform extracts containing a high concentration of baicalein significantly inhibited in vitro NA activity and replication of influenza A virus subtypes, including pandemic $2009 \mathrm{H} 1 \mathrm{~N} 1$ as well as seasonal H1N1 and $\mathrm{H} 3 \mathrm{~N} 2$ influenza A viruses. Comparison of therapeutic index among three extract types indicated EtOAc and chloroform extracts as potential therapeutic agents against influenza A virus. Among the flavonoids, baicalein, the key antiviral component in EtOAc and chloroform extracts, was an NAspecific inhibitor, showing potent anti-influenza A virus activity, yet highly cytotoxic to MDCK cells. Combining lowdose baicalein with other antiviral agents could be alternative remedies against influenza A virus infection.

\section{Disclosure}

Su-Hua Huang is a cofirst author.

\section{Conflict of Interests}

The authors declare no conflict of interests. 


\section{Acknowledgments}

Financial grants were provided by China Medical University (CMU99-NSC-08, CMU100-S-33, and CMU100-ASIA-16), as well as the National Science Council (NSC99-2628-B-039006-MY3). The authors would like to thank Mr. Tai-Lin Chen (Institute of Biochemistry and Molecular Biology, National Yang-Ming University, Taipei, Taiwan) for the assistance of HPLC analysis.

\section{References}

[1] P. F. Wright and R. G. Webster, "Orthomyxoviruses," in Fields Virology, D. M. Knipe and P. M. Howley, Eds., pp. 1533-1579, Lippincott, Philadelphia, Pa, USA, 4th edition, 2001.

[2] A. N. Nicholson, A. R. C. Cummin, and P. L. F. Giangrande, "The airline passenger: current medical issues," Travel Medicine and Infectious Disease, vol. 1, no. 2, pp. 94-102, 2003.

[3] P. M. Colman and M. C. Lawrence, "The structural biology of type I viral membrane fusion," Nature Reviews Molecular Cell Biology, vol. 4, no. 4, pp. 309-319, 2003.

[4] F. Ansaldi, L. Valle, D. Amicizia et al., "Drug resistance among influenza A viruses isolated in Italy from 2000 to 2005: are the emergence of Adamantane-resistant viruses cause of concern?" Journal of Preventive Medicine and Hygiene, vol. 47, no. 1, pp. 1-3, 2006.

[5] R. A. Bright, D. K. Shay, B. Shu, N. J. Cox, and A. I. Klimov, "Adamantane resistance among influenza A viruses isolated early during the 2005-2006 influenza season in the United States," Journal of the American Medical Association, vol. 295, no. 8, pp. 891-894, 2006.

[6] H. G. Cho, J. H. Choi, W. H. Kim et al., "High prevalence of amantadine-resistant influenza A virus isolated in Gyeonggi Province, South Korea, during 2005-2010," Archives of Virology, vol. 158, no. 1, pp. 241-245, 2013.

[7] Q. M. Le, M. Kiso, K. Someya et al., "Avian flu: isolation of drugresistant H5N1 virus," Nature, vol. 437, no. 7062, p. 1108, 2005.

[8] A. Salter, B. Ni Laoi, and B. Crowley, "Emergence and phylogenetic analysis of amantadine-resistant influenza a subtype H3N2 viruses in Dublin, Ireland, over six seasons from 2003/2004 to 2008/2009," Intervirology, vol. 54, no. 6, pp. 305315, 2011.

[9] C. Tosh, H. V. Murugkar, S. Nagarajan et al., "Emergence of amantadine-resistant avian influenza H5N1 virus in India," Virus Genes, vol. 42, no. 1, pp. 10-15, 2011.

[10] S. Tong, Y. Li, P. Rivailler et al., "A distinct lineage of influenza A virus from bats," Proceedings of the National Academy of Sciences of the United States of America, vol. 109, no. 11, pp. 4269-4274, 2012.

[11] A. Trampuz, A. D. Hanssen, D. R. Osmon, J. Mandrekar, J. M. Steckelberg, and R. Patel, "Synovial fluid leukocyte count and differential for the diagnosis of prosthetic knee infection," The American Journal of Medicine, vol. 117, no. 8, pp. 556-562, 2004.

[12] R. J. Garten, C. T. Davis, C. A. Russell et al., "Antigenic and genetic characteristics of swine-origin 2009 A, (H1N1) influenza viruses circulating in humans," Science, vol. 325, no. 5937, pp. 197-201, 2009.

[13] S. U. Schnitzler and P. Schnitzler, "An update on swine-origin influenza virus A/H1N1: a review," Virus Genes, vol. 39, no. 3, pp. 279-292, 2009.
[14] J. Guarner and R. Falcón-Escobedo, "Comparison of the pathology caused by H1N1, H5N1, and H3N2 influenza viruses," Archives of Medical Research, vol. 40, no. 8, pp. 655-661, 2009.

[15] J. Bhatnagar, T. Jones, D. M. Blau et al., "Localization of pandemic 2009 H1N1 influenza A virus RNA in lung and lymph nodes of fatal influenza cases by in situ hybridization: new insights on virus replication and pathogenesis," Journal of Clinical Virology, vol. 56, no. 3, pp. 232-237, 2013.

[16] J.-R. Yang, Y.-P. Huang, Y.-C. Lin et al., "Early findings of oseltamivir-resistant pandemic (H1N1) 2009 influenza A viruses in Taiwan," Antiviral Research, vol. 88, no. 3, pp. 256$262,2010$.

[17] A. C. Hurt, T. Chotpitayasunondh, N. J. Cox et al., "Antiviral resistance during the 2009 influenza A H1N1 pandemic: public health, laboratory, and clinical perspectives," The Lancet Infectious Diseases, vol. 12, no. 3, pp. 240-248, 2012.

[18] R. Gao, B. Cao, Y. Hu et al., "Human infection with a novel avian-origin influenza A, (H7N9) virus," The New England Journal of Medicine, 2013.

[19] K. C. Huang, The Pharmacology of Chinese Herbs, CRC Press, Boca Raton, Fla, USA, 1993.

[20] S. Ikemoto, K. Sugimura, N. Yoshida et al., "Antitumor effects of Scutellariae radix and its components baicalein, baicalin, and wogonin on bladder cancer cell lines," Urology, vol. 55, no. 6, pp. 951-955, 2000.

[21] M. Himeji, T. Ohtsuki, H. Fukazawa et al., "Difference of growth-inhibitory effect of Scutellaria baicalensis-producing flavonoid wogonin among human cancer cells and normal diploid cell," Cancer Letters, vol. 245, no. 1-2, pp. 269-274, 2007.

[22] Z. Błach-Olszewska, B. Jatczak, A. Rak et al., "Production of cytokines and stimulation of resistance to viral infection in human leukocytes by Scutellaria baicalensis flavones," Journal of Interferon and Cytokine Research, vol. 28, no. 9, pp. 571-581, 2008.

[23] M. Li-Weber, "New therapeutic aspects of flavones: the anticancer properties of Scutellaria and its main active constituents Wogonin, Baicalein and Baicalin," Cancer Treatment Reviews, vol. 35, no. 1, pp. 57-68, 2009.

[24] J. Dou, L. Chen, G. Xu et al., "Effects of baicalein on Sendai virus in vivo are linked to serum baicalin and its inhibition of hemagglutinin-neuraminidase," Archives of Virology, vol. 156, no. 5, pp. 793-801, 2011.

[25] G. Xu, J. Dou, L. Zhang, Q. Guo, and C. Zhou, "Inhibitory effects of baicalein on the influenza virus in vivo is determined by baicalin in the serum," Biological and Pharmaceutical Bulletin, vol. 33, no. 2, pp. 238-243, 2010.

[26] Y. Cheng, J. Ping, H.-D. Xu, H.-J. Fu, and Z.-H. Zhou, "Synergistic effect of a noval oxymatrine-baicalin combination against hepatitis $\mathrm{B}$ virus replication, $\alpha$ smooth muscle actin expression and type I collagen synthesis in vitro," World Journal of Gastroenterology, vol. 12, no. 32, pp. 5153-5159, 2006.

[27] Q. Wang, Y.-T. Wang, S.-P. Pu, and Y.-T. Zheng, "Zinc coupling potentiates anti-HIV-1 activity of baicalin," Biochemical and Biophysical Research Communications, vol. 324, no. 2, pp. 605610, 2004.

[28] F. Chen, K. H. Chan, Y. Jiang et al., "In vitro susceptibility of 10 clinical isolates of SARS coronavirus to selected antiviral compounds," Journal of Clinical Virology, vol. 31, no. 1, pp. 6975, 2004.

[29] R.-L. Huang, C.-C. Chen, H.-L. Huang et al., "Anti-hepatitis B virus effects of wogonin isolated from Scutellaria baicalensis," Planta Medica, vol. 66, no. 8, pp. 694-698, 2000. 
[30] A. Kanerva, M. Raki, T. Ranki et al., "Chlorpromazine and apigenin reduce adenovirus replication and decrease replication associated toxicity," Journal of Gene Medicine, vol. 9, no. 1, pp. 39, 2007.

[31] M. Potier, L. Mameli, and M. Belisle, "Fluorometric assay of neuraminidase with a sodium (4-methylumbelliferyl- $\alpha$-D-Nacetylneuraminate) substrate," Analytical Biochemistry, vol. 94, no. 2, pp. 287-296, 1979.

[32] V. D. Zheljazkov, C. L. Cantrell, M. W. Ebelhar, C. Coker, and W. B. Evans, "Quality assessment and yield of Baikal skullcap (Scutellaria baicalensis) grown at multiple locations," HortScience, vol. 42, no. 5, pp. 1183-1187, 2007.

[33] C. Z. Wang, T. D. Calway, X. D. Wen et al., "Hydrophobic flavonoids from Scutellaria baicalensis induce colorectal cancer cell apoptosis through a mitochondrial-mediated pathway," International Journal of Oncology, vol. 42, no. 3, pp. 1018-1026, 2013.

[34] H.-L. Yen, E. Hoffmann, G. Taylor et al., "Importance of neuraminidase active-site residues to the neuraminidase inhibitor resistance of influenza viruses," Journal of Virology, vol. 80, no. 17, pp. 8787-8795, 2006.

[35] K. Zandi, B. T. Teoh, S. S. Sam et al., "Novel antiviral activity of baicalein against dengue virus," BMC Complementary and Alternative Medicine, vol. 12, 214 pages, 2012.

[36] P. Sithisarn, M. Michaelis, M. Schubert-Zsilavecz, and J. Cinatl Jr., "Differential antiviral and anti-inflammatory mechanisms of the flavonoids biochanin A and baicalein in H5N1 influenza A virus-infected cells," Antiviral Research, vol. 97, no. 1, pp. 41-48, 2013.

[37] S. Cotin, C. A. Calliste, M. C. Mazeron et al., "Eight flavonoids and their potential as inhibitors of human cytomegalovirus replication," Antiviral Research, vol. 96, no. 2, pp. 181-186, 2012.

[38] B. Q. Li, T. Fu, Y. Dongyan, J. A. Mikovits, F. W. Ruscetti, and J. M. Wang, "Flavonoid baicalin inhibits HIV-1 infection at the level of viral entry," Biochemical and Biophysical Research Communications, vol. 276, no. 2, pp. 534-538, 2000.

[39] S.-Y. Lyu, J.-Y. Rhim, and W.-B. Park, "Antiherpetic activities of flavonoids against herpes simplex virus type 1 (HSV-1) and type 2 (HSV-2) in vitro," Archives of Pharmacal Research, vol. 28, no. 11, pp. 1293-1301, 2005.

[40] L. Chen, J. Dou, Z. Su et al., "Synergistic activity of baicalein with ribavirin against influenza A (H1N1) virus infections in cell culture and in mice," Antiviral Research, vol. 91, no. 3, pp. 314320, 2011.

[41] T. Nagai, Y. Miyaichi, T. Tomimori, Y. Suzuki, and H. Yamada, "Inhibition of influenza virus sialidase and anti-influenza virus activity by plant flavonoids," Chemical and Pharmaceutical Bulletin, vol. 38, no. 5, pp. 1329-1332, 1990.

[42] T. Nagai, Y. Miyaichi, T. Tomimori, Y. Suzuki, and H. Yamada, "In vivo anti-influenza virus activity of plant flavonoids possessing inhibitory activity for influenza virus sialidase," Antiviral Research, vol. 19, no. 3, pp. 207-217, 1992.

[43] T. Nagai, R. Moriguchi, Y. Suzuki, T. Tomimori, and H. Yamada, "Mode of action of the anti-influenza virus activity of plant flavonoid, 5,7,4'-trihydroxy-8-methoxyflavone, from the roots of Scutellaria baicalensis," Antiviral Research, vol. 26, no. 1, pp. 11-25, 1995.

[44] Y. P. Tseng, Y. C. Wu, Y. L. Leu, S. F. Yeh, and C. K. Chou, "Scutellariae radix suppresses hepatitis B virus production in human hepatoma cells," Frontiers in Bioscience, vol. 2, pp. 15381547, 2010.
[45] B. P. Burnett, Q. Jia, Y. Zhao, R. M. Levy, and S. Chen, "A medicinal extract of Scutellaria baicalensis and Acacia catechu acts as a dual inhibitor of cyclooxygenase and 5-lipoxygenase to reduce inflammation," Journal of Medicinal Food, vol. 10, no. 3, pp. $442-451,2007$. 


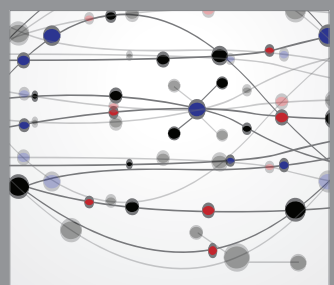

The Scientific World Journal
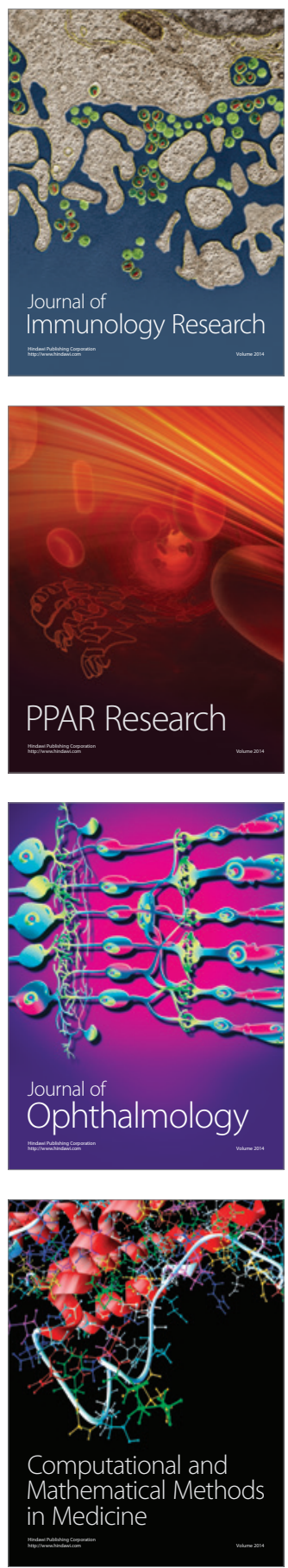

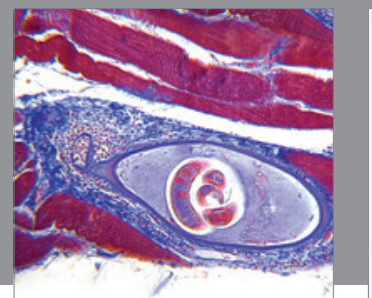

Gastroenterology

Research and Practice
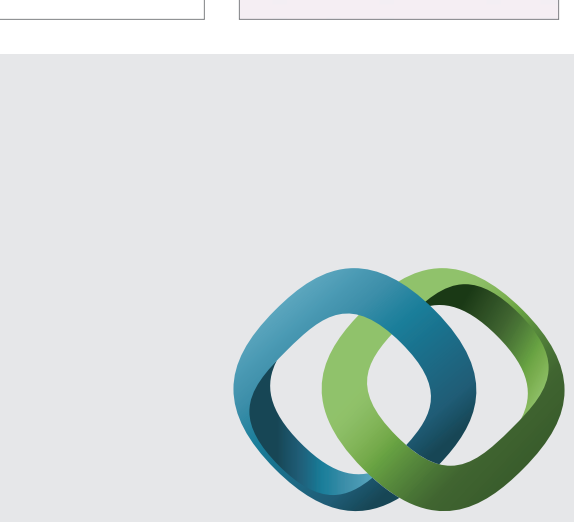

\section{Hindawi}

Submit your manuscripts at

http://www.hindawi.com
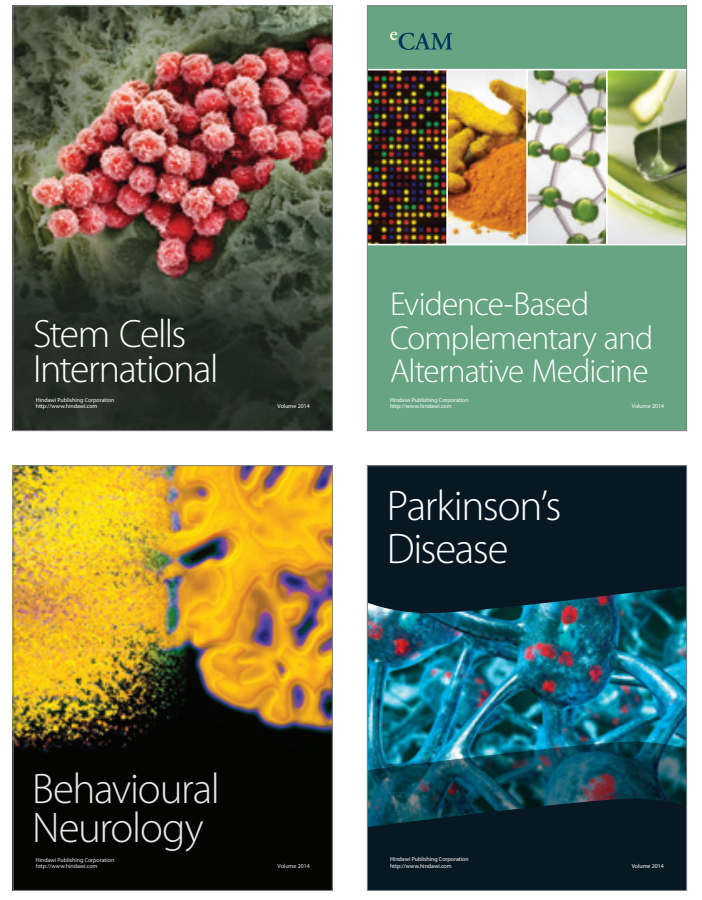
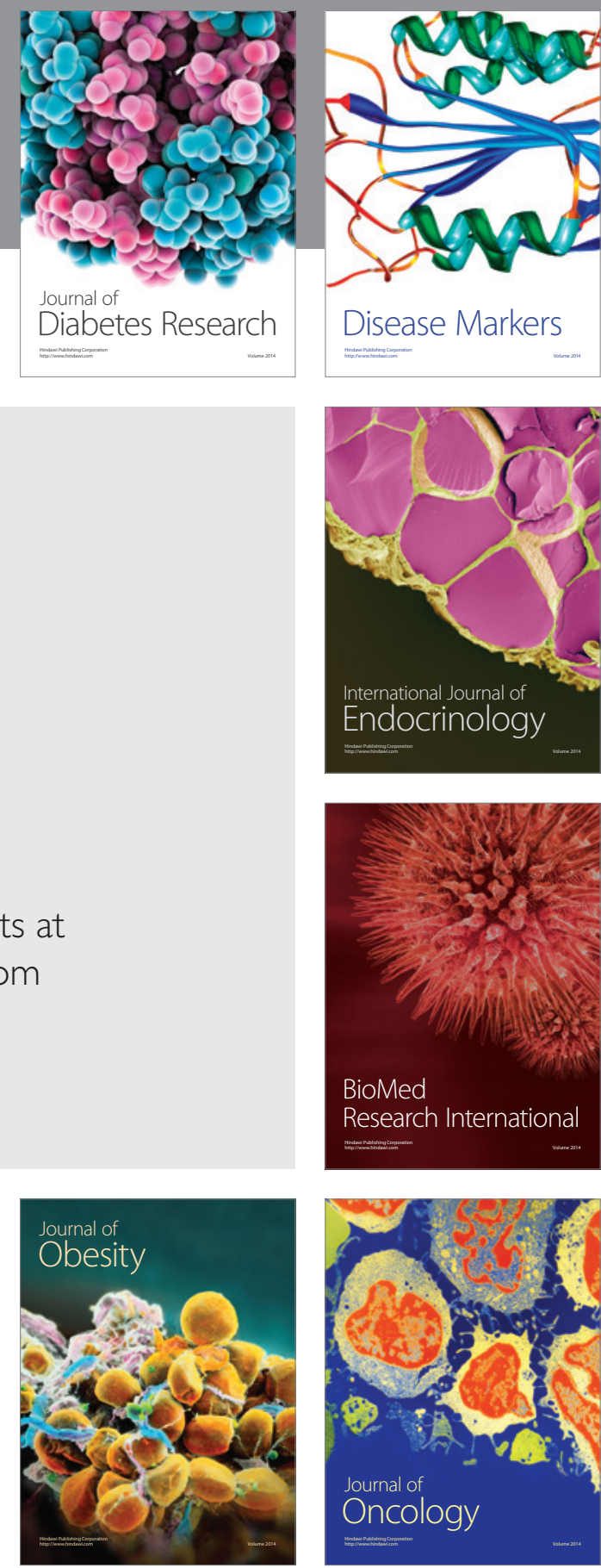

Disease Markers
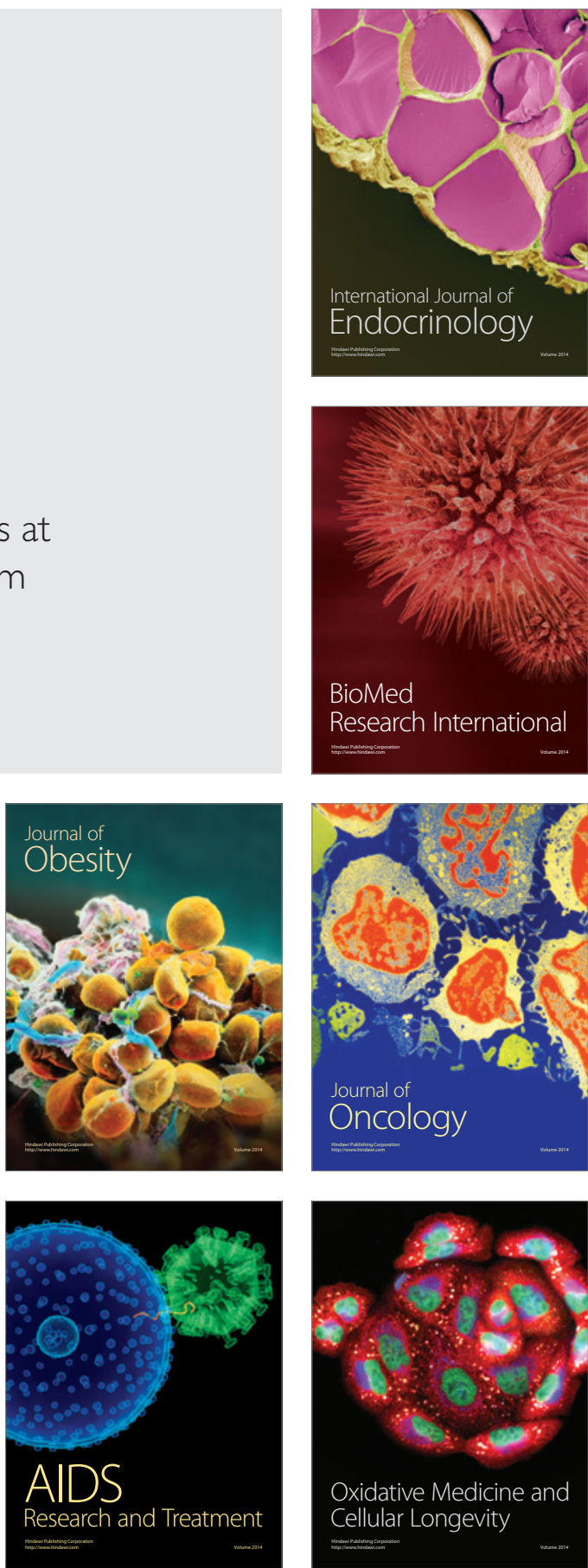